\title{
The link between school climate and violence in school: A meta-analytic review
}

Citation for published version (APA):

Steffgen, G., Recchia, S., \& Viechtbauer, W. (2013). The link between school climate and violence in school: A meta-analytic review. Aggression and Violent Behavior, 18(2), 300-309. https://doi.org/10.1016/j.avb.2012.12.001

Document status and date:

Published: 01/01/2013

DOI:

10.1016/j.avb.2012.12.001

Document Version:

Publisher's PDF, also known as Version of record

Document license:

Taverne

Please check the document version of this publication:

- A submitted manuscript is the version of the article upon submission and before peer-review. There can be important differences between the submitted version and the official published version of record.

People interested in the research are advised to contact the author for the final version of the publication, or visit the DOI to the publisher's website.

- The final author version and the galley proof are versions of the publication after peer review.

- The final published version features the final layout of the paper including the volume, issue and page numbers.

Link to publication

\footnotetext{
General rights rights.

- You may freely distribute the URL identifying the publication in the public portal. please follow below link for the End User Agreement:

www.umlib.nl/taverne-license

Take down policy

If you believe that this document breaches copyright please contact us at:

repository@maastrichtuniversity.nl

providing details and we will investigate your claim.
}

Copyright and moral rights for the publications made accessible in the public portal are retained by the authors and/or other copyright owners and it is a condition of accessing publications that users recognise and abide by the legal requirements associated with these

- Users may download and print one copy of any publication from the public portal for the purpose of private study or research.

- You may not further distribute the material or use it for any profit-making activity or commercial gain

If the publication is distributed under the terms of Article $25 \mathrm{fa}$ of the Dutch Copyright Act, indicated by the "Taverne" license above, 


\title{
The link between school climate and violence in school: A meta-analytic review
}

\author{
Georges Steffgen $^{\mathrm{a}, *}$, Sophie Recchia ${ }^{\mathrm{a}}$, Wolfgang Viechtbauer ${ }^{\mathrm{b}}$ \\ a University of Luxembourg, Luxembourg \\ b University of Maastricht, The Netherlands
}

\section{A R T I C L E I N F O}

\section{Article history:}

Received 14 August 2012

Received in revised form 2 December 2012

Accepted 4 December 2012

Available online 12 December 2012

\section{Keywords:}

School climate

School violence

Meta-analysis

\begin{abstract}
A B S T R A C T
There has been significant interest in whether and how school climate and violent behavior are meaningfully related. The present meta-analysis reviewed studies reporting a relationship between school climate and school violence in order to summarize the total effect and the direction of these research findings. Database consultation and literature hand searching yielded 145 articles which were reviewed by two experts. Studies were included if they reported a statistical effect size of the relationship between school climate and school violence. Exclusion criteria were unclear operationalization of the principal variables, research findings from multiple publications, studies using multi-level analysis and qualitative studies. The meta-analysis included 36 independent studies $(N=113,778)$ with correlations ranging from -.02 to -.53 . Using a random-effects model a moderate mean effect size of $r=-.26, \mathrm{CI}[-30,-21]$ was found. Statistical findings indicated significant heterogeneity and a large range of variance between studies. Meta-regressions analyzed different potential moderators as relevant factors of heterogeneity, but none of these factors could be identified as a moderator. Due to the large variance between the studies, it remains difficult to draw final conclusions. Nevertheless, the moderate effect size underlines the role of environmental aspects for school violence intervention.
\end{abstract}

(c) 2012 Elsevier Ltd. All rights reserved.

\section{Contents}

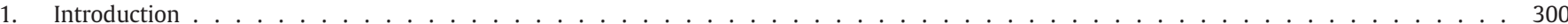

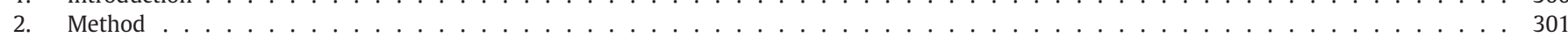

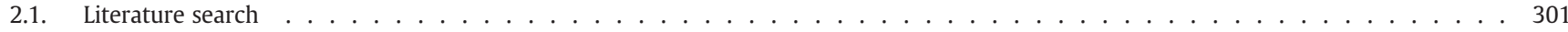

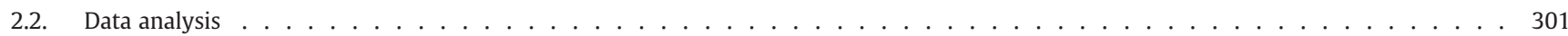

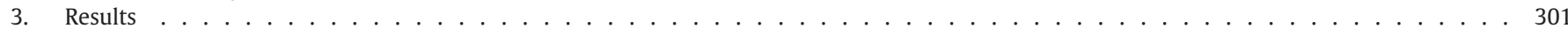

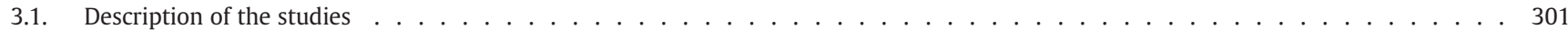

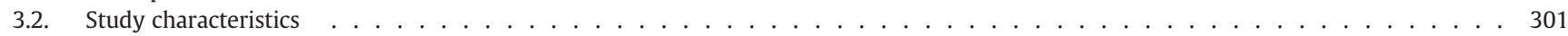

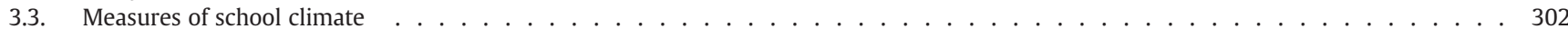

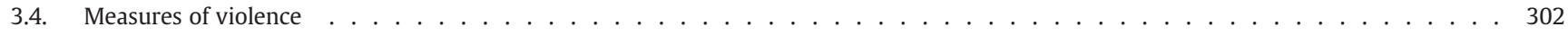

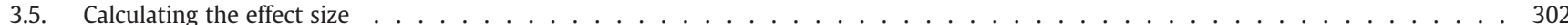

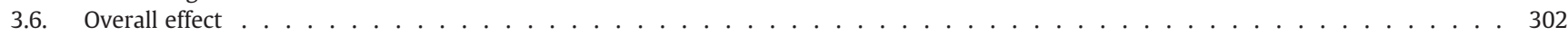

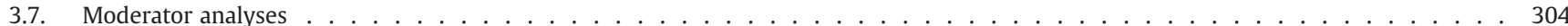

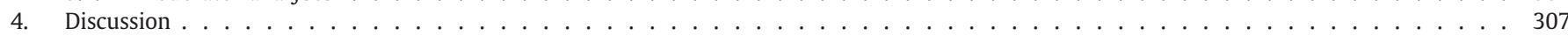

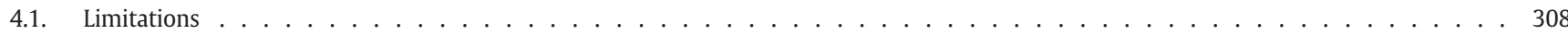

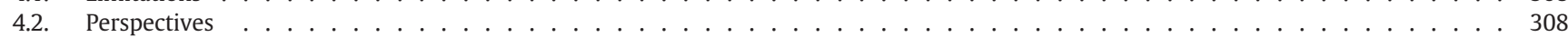

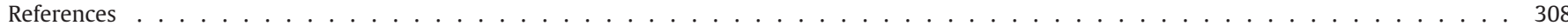

\footnotetext{
* Corresponding author at: Université du Luxembourg, Campus Walferdange, Research Unit INSIDE, Bâtiment XII; Bureau 1.05, Route de Diekirch, L-7201 Walferdange Luxembourg. Tel.: +352466644 6644; fax: + 3524666449535 .

E-mail address: georges.steffgen@uni.lu (G. Steffgen).
}

\section{Introduction}

School violence remains a very important social issue world-wide (Debarbieux, 2006). A large number of students in schools are affected negatively by it, in the short term as well as in the long term (Gottfredson, 2001). In terms of conceptualization, violence at school is a very heterogeneous phenomenon (Debarbieux, 2006; 
Smith, 2005; Smith, Ananiadou, \& Cowie, 2003). School violence includes a wide range of behaviors that threaten and harm others emotionally and physically: ranging from intentional physical attacks including the use of weapons, gang violence and sexual assaults, to less serious behaviors like beating and slapping, to relatively harmless kicks and punches (Fuchs, 2009). In general, violence (in schools) as a specific form of risk behavior can be defined as a purposeful damage in form of a physiological or psychological action that is directed against the self, other persons (student against student, student against teacher, teacher against teacher or teacher against student), or against objects (Steffgen, 2009). In contrast, bullying as a specific form of violence is marked as the systematic and repeated harassment of weaker people. It mostly emerges as a group phenomenon (Olweus, 2004; Smith, 2000). In summary, research studies on school violence differ strongly in the use of definitions and concepts.

During the last 20 years there has been extensive research on identifying risk factors for school violence (Benbenishty, Astor, Zeira, \& Vinokur, 2002). The concept of school climate has received particular attention (Freiberg, 1999). Most importantly, the social climate in class and in school is assumed to have a significant effect on the prevalence of violence in schools (Janosz, Georges, \& Parent, 1998; Janosz, Thiébaud, Bouthillier, \& Brunet, 2005).

Thus, different theoretical approaches have been considered. The ecological development theory allows conceptualizing the impact of school climate on school violence (Bronfenbrenner, 1974). School violence is here defined as a behavioral expression located in the microsystem, but strongly influenced by the mesosystem (interpretation of school climate). A distinction is made between school violence as an act (behavior) versus school climate (cognitive and emotion interpretation) as the subjective and objective reality of the school subsystem. Bridging the two concepts together, the psychological process (psychosocial) of school climate interpretation plays an important role in school violence.

Continual attempts have been undertaken to identify key components of school climate. Therefore, existing school climate taxonomies offer different opportunities to categorize various dimensions (Moos, 1979). Some categorizations are defining climate variables as affective, if they are related to interpersonal and social relations (e.g., school belonging, student participation), as cognitive or affective, when psychological processes are involved (e.g., school attachment, school fear), and as organizational when referring to school specific variables (e.g., school security, school management) (Fraser, 1994).

There is a broad consensus among researchers that school climate is an important factor that warrants further investigation with regard to violence (Carra, 2009; Gottfredson, Gottfredson, Payne, \& Gottfredson, 2005; Hernandez \& Seem, 2004). However, the lack of clear definitions, taxonomies, and empirically-validated measures of school climate has resulted in a multitude of findings that are often difficult to interpret. The lack of quantitative reviews on the relationship between school climate and violence may, in part, be due to the conceptual uncertainty regarding the definition of school climate (Johnson, 2009).

Nevertheless, the purpose of the meta-analysis reported here is to investigate the relationship between school climate and school violence. Knowing the proliferation of concepts of school climate as well as of violence, there is still need for an integrative quantitative review that allows more clarity about the relationship between climate and violence. Thus, the primary aim of this study is to explore, by analyzing the statistical results of a collection of empirical research studies, if a relevant effect size could be detected between the relationship of school climate and school violence. Additionally, this meta-analysis' second target is to test if potential moderators may have an impact on the association of school climate and school violence.

\section{Method}

\subsection{Literature search}

A literature search was conducted to identify studies analyzing the impact of students' perceptions of school climate on violent behavior at school. The following search equation was chosen (aggress* or violen* or bully* and climate) in databases' specific fields (keywords, title or abstracts). Electronic databases were consulted (PsycInfo, Pubmed, EBSCO, Science Direct, ISI WEB of Knowledge, PROQUEST) for peer-reviewed journal articles written in English, French, or German. Periodical databases' alerts coded with the same search equation were consulted regularly. Studies were also sought from experts in the field, by a call made through the international observatory on school violence. This strategy identified 598 references.

Inclusion criteria specified studies that statistically analyzed the link between school climate and violence, and which used quantitative methods with objective, standardized, or validated self-report instruments. Exclusion criteria were studies using qualitative data, studies with unclear operationalization, research findings from multiple publications and studies using multi-level analysis. Hand search yielded 41 additional studies. The remaining 76 relevant studies were screened independently by two reviewers, with a satisfactory intercoder reliability of inclusion agreement ( $r$ Cohen's kappa ranged from $.62^{* *}$ to $98^{* *}$ ). Disagreements were resolved through discussion and consulting a third reviewer. For studies with insufficient statistical information, the authors were contacted with a response rate of $62 \%$. Finally, 36 studies have been included in the present metaanalysis.

\subsection{Data analysis}

The data for the meta-analysis consist of 36 correlations measuring the direction and strength of the relationship between school climate and school violence. The goal of the meta-analysis was to examine the overall relationship between these two variables and to assess a number of potential moderators of this relationship. The analyses were conducted with the statistical package Comprehensive Meta-Analysis (Biostat, 2008), as well as with R (version 2.14.0), using the metafor package (version 1.6-0, Viechtbauer, 2010).

\section{Results}

\subsection{Description of the studies}

This meta-analysis included 36 studies reporting statistical effects of the relationship between school climate and school violence. These 36 empirical studies have been identified through literature search of published and non-published research. Taken together, studies came from different research fields (educational, psychosocial, and epidemiological domain); and studies' aims were divergent. Nevertheless, in the 36 studies, the environmental impact of school climate on school violence was analyzed. Table 1 provides an overview of the included studies' main purposes.

\subsection{Study characteristics}

The present meta-analysis included 36 studies reporting an association between school climate and school violence. Concerning the characteristics of the studies included in the meta-analysis, the total population analyzed $(N=113,778)$ has a mean age of $13.53(1.44 \mathrm{SD})$ and a mean male percentage of $46.9 \%$. Individual populations studied were elementary, middle, or high school students. Included studies had samples covering different numbers of schools varying from 1 to 528 schools. Data were collected at different times ranging from 1982 to 2008 in different countries across North America, Europe, and Asia. 
Table 1

Overview of the included studies' main purpose.

\begin{tabular}{|c|c|}
\hline Study & Study's purpose \\
\hline Astor, Benbenishty, Vinokur, and Zeira (2006) & School context variables influence on students' fear of going to school \\
\hline Bayraktar (2011) & Multifactor model of bullying among adolescents in North Cyprus and Turkey \\
\hline Benbenishty et al. (2002) & Analyze of context and victimization impacts on nonattendance at school \\
\hline Bosworth, Eseplage, and Simon (1999) & Association between misconduct and prosocial behaviors with involvement in bullying \\
\hline Brookmeyer, Fanti, and Henrich (2006) & Effects of school connectedness as buffers of violent behaviors \\
\hline Cernkovich and Giordano (1992) & Impact of school bonding on delinquent conduct \\
\hline Crooks, Scott, Wolfe, Chiodo, and Killip (2007) & Influence of school level variables on delinquency \\
\hline Cushing, Horner, and Barrier (2003) & Identifying variables that maintain inappropriate behaviors in schools \\
\hline Dunn $(2001)$ & Relations among achievement and school factors (violence, climate, anxiety) \\
\hline Frey, Ruchkin, Martin, and Schwab-Stone (2009) & Protective role of school attachment and family involvement \\
\hline Galand, Philippot, Petit, Born, and Buidin (2004) & Frequency and impact of different types of victimization in school \\
\hline Goldstein, Young, and Boyd (2008) & Association of relational aggression and participation in a hostile school environment \\
\hline Graham, Bellmore, and Mize (2006) & Relations between aggression and school difficulties \\
\hline Henrich, Brookmeyer, and Shahar (2005) & Links between violence exposure, parent and school connectedness \\
\hline Jenkins (1997) & Effects of school social bond on crime, misconduct and nonattendance in schools \\
\hline Karwowski (2008) & Influence of perceived school climate on risk behaviors among adolescents \\
\hline Kasen, Berenson, Cohen, and Johnson (2004) & Effect of school climate on concurrent behaviors related to bullying process \\
\hline Klicpera, Gasteiger, and Schabmann (1995) & Contribution of school-specific factors to aggressive behavior \\
\hline Kuperminc, Leadbeater, Emmons, and Blatt (1997) & Impact of school climate on student behavioral problems and emotional distress \\
\hline Lee $(2010)$ & Prediction model of bullying behaviors \\
\hline Loukas, Suzuki, and Horton (2006) & Relations between connectedness, school climate, conduct problems and depressive symptoms \\
\hline Miller (2006) & Perceptions of school climate and attitudes towards bullying among students and teachers \\
\hline Mohr (1999) & Impact of peer victimization on adolescent's mental health \\
\hline Nansel, Haynie, and Simons-Morton (2007) & Bullying behaviors and middle school adjustment \\
\hline (O'Brennan, Bradshaw, and Sawyer (2009) & Associations between bullying and aggressive behaviors and perceptions of school climate \\
\hline Pfetsch (2010) & Impact of prosocial behaviors on violence in schools \\
\hline Roland and Galloway (2002) & Relations between class factors (teachers' management, social structure) and bullying \\
\hline Schechtman (2006) & Relationship between life skills, classroom climate and self-reported levels of victimization \\
\hline Steffgen (2004) & Examination of school culture and violence \\
\hline Stewart (2003) & Analyze of factors explaining school misbehavior \\
\hline Sturzbecher, Landua, and Shahla (2001) & Examination of the disposition to aggression in a specific area of Germany \\
\hline Swearer et al. (2006) & Model of bullying and victimization in early adolescence \\
\hline Tillmann, Holler-Nowitzki, Holtappels, Meier, and Popp (1997) & Impact of organizational school characteristics on violence behavior of students \\
\hline Welsh (2001) & Indicators of school disorder \\
\hline Willoughby et al. (2007) & Analyze of adolescent non-involvement in multiple risk behaviors \\
\hline Wilson (2004) & Effects of connectedness and climate on measures of aggression and victimization \\
\hline
\end{tabular}

Detailed characteristics of the studies included in the meta-analysis are listed in Table 2.

\subsection{Measures of school climate}

Studies included in the meta-analysis made use of multiple different measures of school climate. Referring to existing classification (Moos, 1979), measures of the school climate have been grouped into three categories: (1) the relational dimension refers to interpersonal relations within the school (e.g., teacher-student relationships, cohesion); (2) the cognitive/affective dimension refers to perceptions or feelings toward the school (e.g., attachment, belongings); (3) the organizational dimension refers to a school's characteristics (e.g., security, rules).

\subsection{Measures of violence}

Studies measured school violence with various instruments, and examined committed, experienced, and general perception of violence: (1) the violence committed dimension refers to engagement in various aggressive behaviors (e.g., physical aggression, verbal aggression, weapon use); (2) the violence experienced dimension refers to being victim of various aggressive behaviors (e.g., physical aggression, verbal aggression, weapon use); (3) the perception of violence in school dimension refers to the general feeling of on an insecure school (e.g. overall problem behaviors).

\subsection{Calculating the effect size}

The 36 studies provided correlations of the relationship between school climate and school violence with a high level of variability.
Fig. 1 below provides an overview of the distribution of the observed correlations in the form of a histogram. All of the correlations were below 0 , indicating that an increasing positive school climate is related to a decrease in school violence (and vice-versa). However, the strength of the correlation varied considerably (range: -.53 to -.02$)$.

\subsection{Overall effect}

To obtain an estimate of the average correlation, the observed correlations were first transformed via Fisher's r-to-z transformation (Fisher, 1921), and then meta-analyzed using a fixed- and a randomeffects model (Konstantopoulos \& Hedges, 2009; Raudenbush, 2009). The estimated average transformed correlation and the bounds of the corresponding 95\% confidence interval (CI) were then back-transformed to correlation units for easier interpretation. The DerSimonian-Laird estimator was used to estimate the amount of heterogeneity in the random-effects model (DerSimonian \& Laird, 1986). The correlations were tested for heterogeneity via the Q-test (Cochran, 1954). In addition, the amount of heterogeneity (in terms of $\hat{\tau}$, the estimated standard deviation of the true (transformed) correlations), the $I^{2}$ statistic (Higgins, Thompson, Deeks, \& Altman, 2003), and an approximate $95 \%$ credibility interval (indicating the range where 95\% of the true correlations are expected to fall) were obtained (Riley, Higgins, \& Deeks, 2011).

The correlations were clearly heterogeneous, as indicated by the test for heterogeneity $(Q=2271.24, d f=35, p<.0001)$ and by the $I^{2}$ statistic ( $I^{2}=98.5 \%$, indicating that almost all of the variability observed in the (transformed) correlations was due to heterogeneity in the true correlations and not simply due to sampling variability). Based on the fixed-effects model, the estimated average correlation was $-.22(95 \% \mathrm{CI}:-.21$ to -.22$)$. On the other hand, the random- 
Table 2

Studies' characteristics of the studies included in the meta-analysis.

\begin{tabular}{|c|c|c|c|c|c|c|}
\hline Study & Age & Male percentage & School grade & Number of schools & Country & Survey year \\
\hline Astor et al. (2006) & - & 48 & $4-6$ & 71 & Israel & 1998 \\
\hline Bayraktar (2011) & 14.7 & 46.9 & $7-12$ & - & Turkey & - \\
\hline Benbenishty et al. (2002) & - & 44 & $7-9$ & 102 & Israel & 1998 \\
\hline Bosworth et al. (1999) & 12.4 & 46 & $6-8$ & 1 & USA & 1995 \\
\hline Brookmeyer et al. (2006) & 15.54 & 46 & $7-12$ & 125 & USA & 1994 \\
\hline Cernkovich and Giordano (1992) & - & 49 & $7-12$ & 51 & USA & 1982 \\
\hline Crooks et al. (2007) & 13.5 & 49 & 9 & 23 & USA & 2005 \\
\hline Cushing et al. (2003) & - & 49 & $4-8$ & 15 & USA & 2000 \\
\hline Dunn (2001) & - & 43 & $6-8$ & 1 & USA & 2000 \\
\hline Frey et al. (2009) & 13.62 & 45 & 9 & 17 & USA & 2004 \\
\hline Galand et al. (2004) & - & 51 & $7-12$ & 45 & Belgium & 2000 \\
\hline Goldstein et al. (2008) & 14.78 & 48 & $7-12$ & 130 & USA & 2007 \\
\hline Graham et al. (2006) & 11.5 & 46 & 6 & 11 & USA & 2005 \\
\hline Henrich et al. (2005) & - & 48 & $7-12$ & 132 & USA & 1995 \\
\hline Jenkins (1997) & - & 50 & $7-8$ & 1 & USA & 1990 \\
\hline Karwowski (2008) & 15.21 & 54.5 & - & 1 & Poland & - \\
\hline Kasen et al. (2004) & 14.9 & 49.6 & $5-12$ & - & USA & 1985 \\
\hline Klicpera et al. (1995) & 14 & - & 8 & 79 & Austria & 1993 \\
\hline Kuperminc et al. (1997) & 12.8 & 49 & $6-7$ & 1 & USA & - \\
\hline Lee $(2010)$ & - & 52.8 & $6-8$ & - & USA & 2008 \\
\hline Loukas et al. (2006) & 11.69 & 49 & $6-7$ & 3 & USA & - \\
\hline Miller (2006) & - & 52 & $7-8$ & 3 & USA & - \\
\hline Mohr (1999) & 13.28 & 61 & $5-9$ & 2 & Germany & 1996 \\
\hline Nansel et al. (2007) & - & 47 & $4-7$ & 4 & USA & 1996 \\
\hline O'Brennan et al. (2009) & - & 50 & $4-12$ & 105 & USA & 2006 \\
\hline Pfetsch (2010) & 11.96 & 48.8 & $2-12$ & 13 & Luxembourg & 2007 \\
\hline Roland Galloway (2002) & 11.4 & 48 & $4-6$ & 22 & Norway & 1998 \\
\hline Schechtman (2006) & - & 50 & $4-6$ & 97 & Israel & \\
\hline Steffgen (2004) & - & 49.2 & $7-11$ & 1 & Luxembourg & 2001 \\
\hline Stewart (2003) & - & - & 10 & 528 & USA & 1990 \\
\hline Sturzbecher et al. (2001) & 15 & 49 & $7-13$ & - & Germany & 1999 \\
\hline Swearer et al. (2006) & 13.06 & 44 & $6-9$ & 3 & USA & 2000 \\
\hline Tillmann et al. (1997) & - & -9 & $6-10$ & 24 & Germany & 1997 \\
\hline Welsh (2001) & 12.12 & 48 & $6-8$ & 11 & USA & 1994 \\
\hline Willoughby et al. (2007) & 15.71 & 49 & $9-12$ & 25 & Canada & - \\
\hline Wilson (2004) & - & - & $6-12$ & 19 & USA & 2001 \\
\hline
\end{tabular}

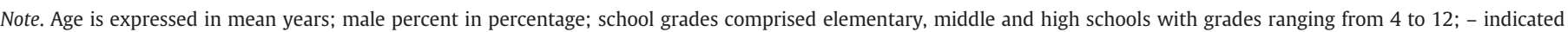
missing values.

effects model yielded an estimated average correlation of - .26 (95\% $\mathrm{CI}:-.21$ to -.30$)$ and, given the large amount of heterogeneity $(\hat{\tau}=$ $.15)$, a very wide $95 \%$ credibility interval ( -.51 to .03 ). Fig. 2 shows a forest plot of the 36 correlations (with $95 \%$ CIs for each study) and the estimated average correlation (with $95 \% \mathrm{CI}$ ) based on the randomeffects model. The horizontal dashed line around the estimated average correlation indicates the $95 \%$ credibility interval.

Note that the fixed-effects model provides a conditional inference about the set of studies included in the meta-analysis (and, hence, an estimate of the average true correlation in those 36 studies), while the random-effects model provides an unconditional inference

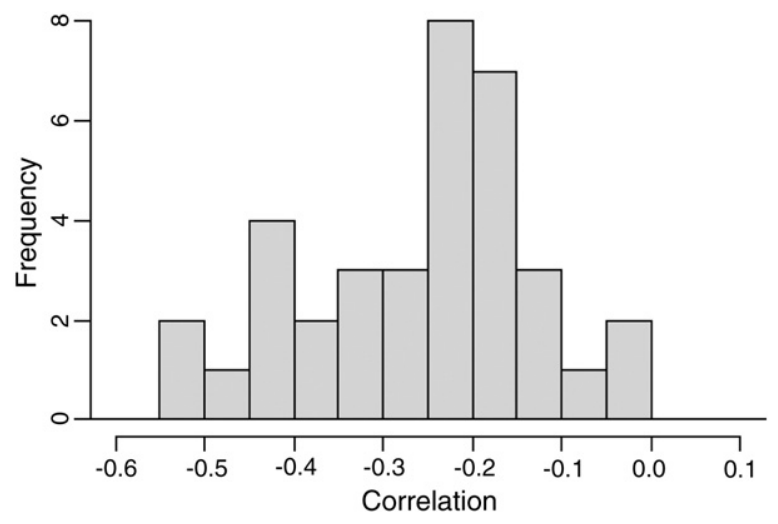

Fig. 1. Histogram of observed correlations. about a hypothetical population of studies (and hence, an estimate of the average true correlation in the population of studies) from which the 36 studies are assumed to be randomly drawn (Hedges \& Vevea, 1998).

Removal of each study, in turn, did not yield any appreciable differences in the conclusions. A wide variety of outlier and influential case diagnostics are shown in Fig. 3, including externally standardized residuals, DFFITS values, Cook's distances, covariance ratios, leave-one-out estimates of the amount of heterogeneity, leave-oneout heterogeneity test statistics, hat values, and weights (Viechtbauer \& Cheung, 2010). There is no indication of any particular study being an outlier or exerting an undue influence on the results.

Fig. 4 shows a funnel plot (Light \& Pillemer, 1984) of the transformed correlations. The white, light-gray, and dark-gray shaded areas indicate $90 \%, 95 \%$ and $99 \%$ pseudo confidence interval regions under the assumption that the true correlations are homogeneous (Peters, Sutton, Jones, Abrams, \& Rushton, 2008). Due to the large amount of heterogeneity, the observed correlations often fall outside of these regions. There appears to be no indication that correlations on one side of the funnel plot have been systematically suppressed. The regression test for funnel plot asymmetry (Egger, Davey Smith, Schneider, \& Minder, 1997) based on a random/mixed-effects model (Sterne \& Egger, 2005) was not significant $(p=.32)$. The rank correlation test (Begg \& Mazumdar, 1994) also did not indicate any asymmetry in the funnel plot $(p=.95)$. The trim-and-fill method (Duval \& Tweedie, 2000a, 2000b) based on a random-effects model (Duval, 2005) suggested the possibility of five missing studies on the left side of the funnel. The estimate of the average correlation was -.29 (95\% CI: -.23 to -.34 ) following the imputation of these potentially 


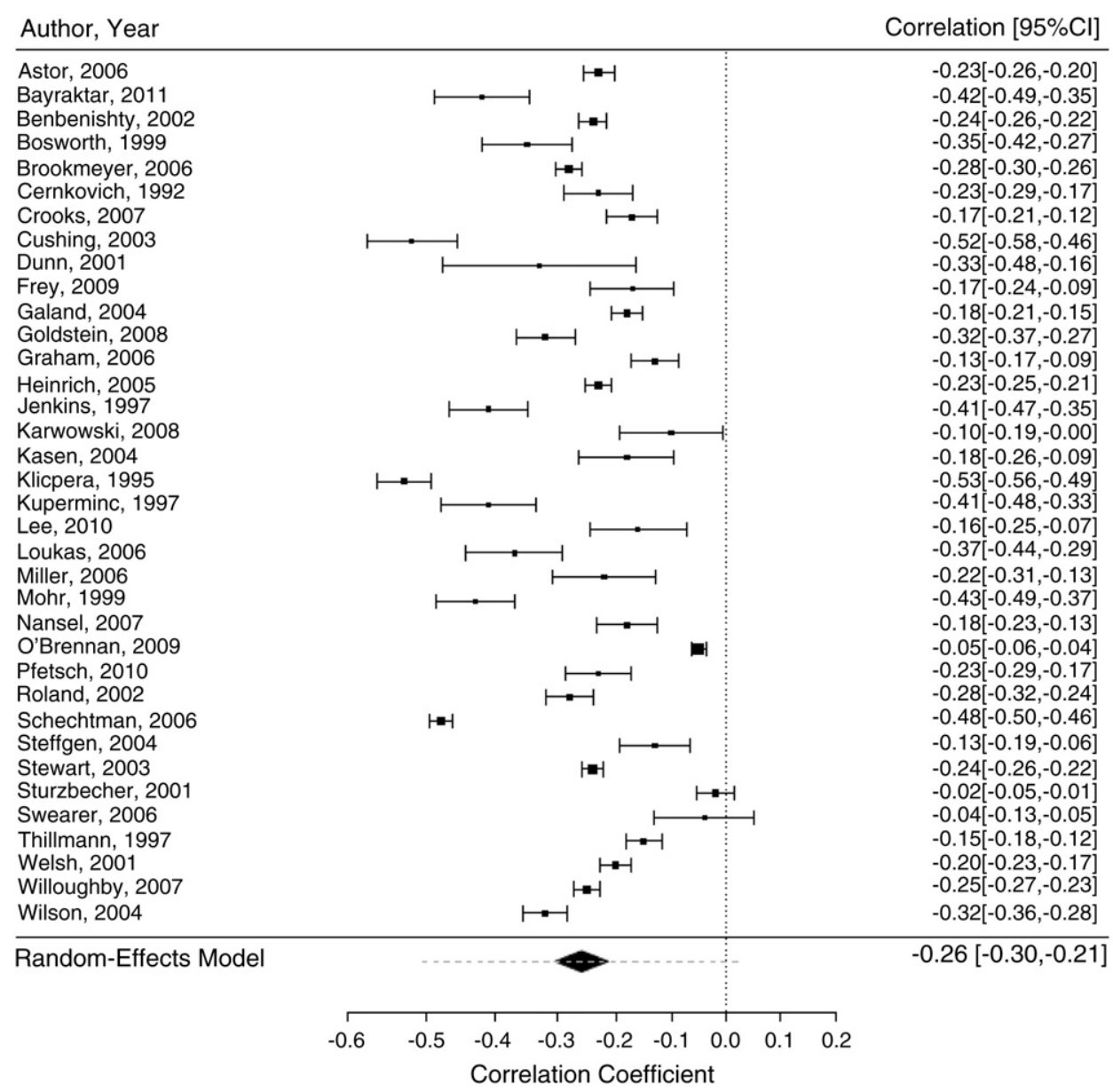

Fig. 2. Forest plot of the 36 correlations.

missing studies, a negligible difference in comparison with the results obtained earlier.

\subsection{Moderator analyses}

Moderator analyses were carried out using mixed-effects (metaregression) models (Raudenbush, 2009) and using the mixed-effects model analogue of the DerSimonian-Laird estimator to estimate the amount of residual heterogeneity. Moderators were first tested individually (i.e., by means of univariate models) and then simultaneously (i.e., by means of a multiple meta-regression model) with backwards elimination to obtain a final model (with $p>.10$ for removal). A pseudo- $R^{2}$ statistic is given for each model, indicating the amount of heterogeneity that is accounted for by the moderator(s) included in the model. The Knapp and Hartung method, which provides accurate control of the Type I error rate, was used to adjust the test statistics of the moderator variables (Knapp \& Hartung, 2003).

The following moderators were tested: peer reviewed study (yes, no), mean age of the study sample (analyzed as a continuous moderator), percentage of males in the study sample (continuous moderator), school grade of the study sample (continuous moderator by the following classification elementary schools (1); elementary and middle schools (2), middle schools (3), elementary, middle and high schools (4), middle and high schools (5) and high schools (6), year in which the data were collected (continuous moderator), number of schools in the study (continuous moderator), continent on which the study was carried out (North America, Europe, and Asia), violence dimension (violence committed, violence experienced, and general perception of violence), climate dimension (relational, cognitive-affective, and organizational), and publication year (continuous moderator). Categorical moderators were dummy-coded for the analysis.

Fig. 5 provides scatterplots for each of the six continuous moderators. The points are drawn proportional to the size of the studies (i.e., larger points indicate larger studies and, therefore, more precise estimates). The regression line (with pointwise 95\% CIs) as estimated from the meta-regression model is added to each plot. Note that the number of schools was very large in one study in comparison to the rest of the investigations. Removal of that study from the analysis did not alter the conclusions for this moderator.

Table 3 provides the results for the (univariate) mixed-effects meta-regression models when analyzing the continuous moderators. Except for the variable publication year (which just barely misses the $\alpha=.05$ cutoff), there was there no indication of a moderating effect for this set of variables.

Fig. 6 shows a cumulative forest plot, indicating the estimated average correlation based on a random-effects model as a function of the publication year of the study. The size of the estimated average correlation decreases slightly over time.

Table 4 provides the results for the (univariate) meta-regression models when analyzing the categorical moderators. None of the moderators reached significance at $\alpha=.05$. Also, none of the pairwise comparisons between the levels of a categorical moderator reached statistical significance.

Since the survey year and publication year variables were strongly correlated $(r=.70)$, only publication year (which had no missing data) was entered into the multiple meta-regression model. Also, the mean age of the study sample was unknown for 17 of the 36 studies (47\%), so that inclusion of this moderator would severely reduce 


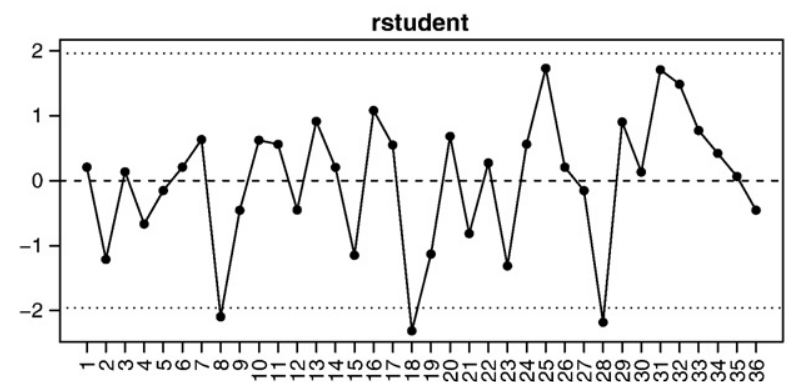

cook.d
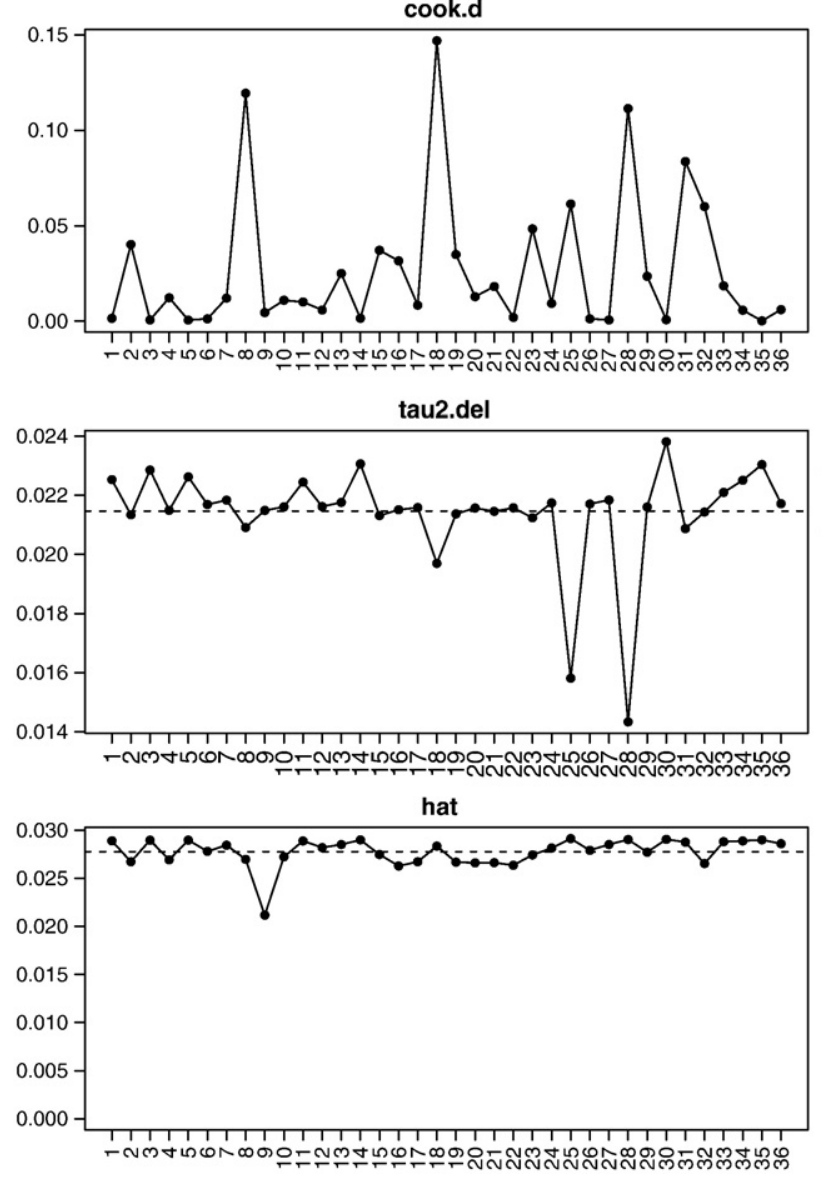

dffits

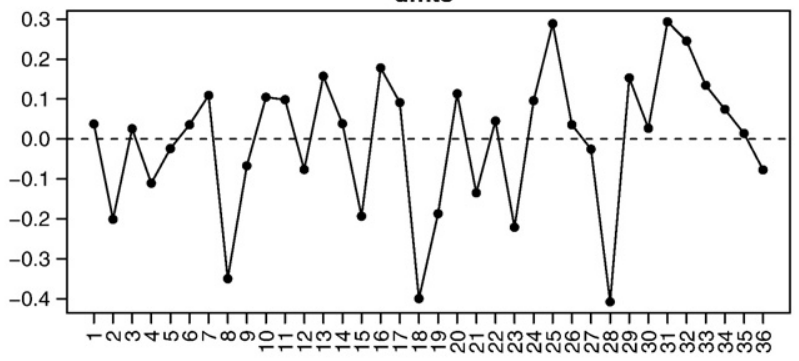

cov.r
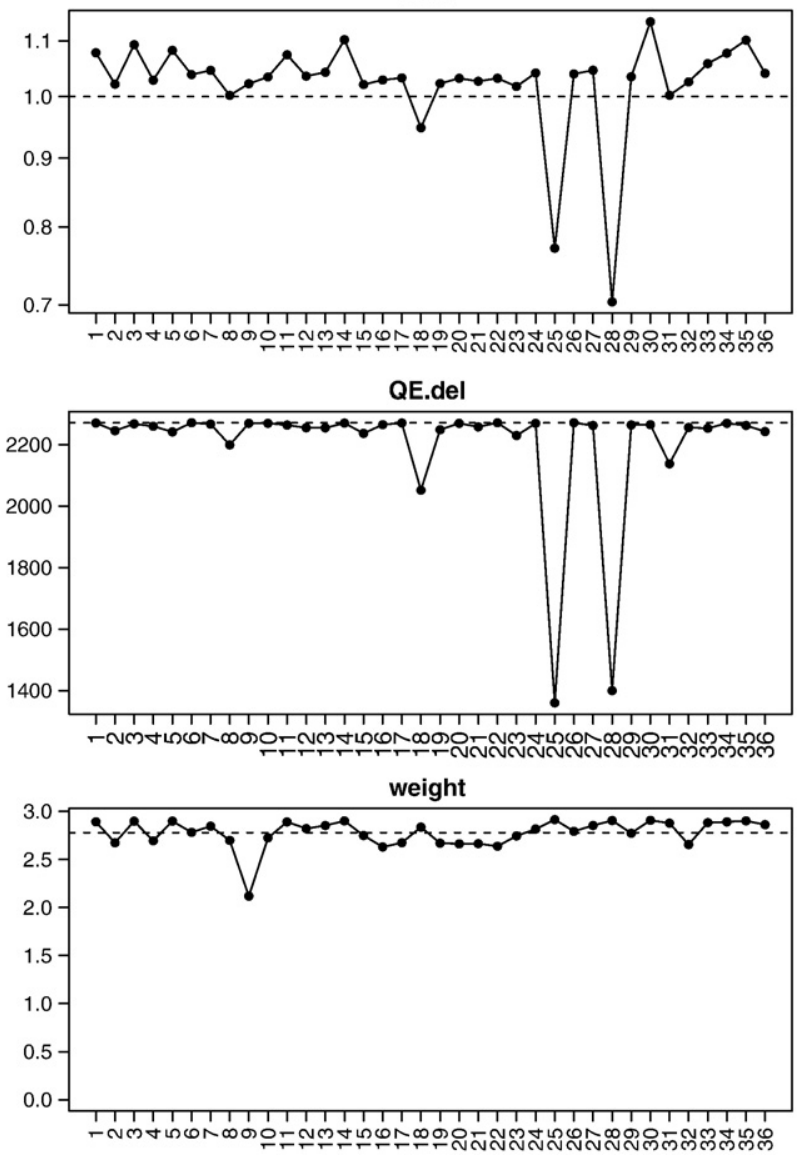

Fig. 3. Outlier and influential case diagnostics.

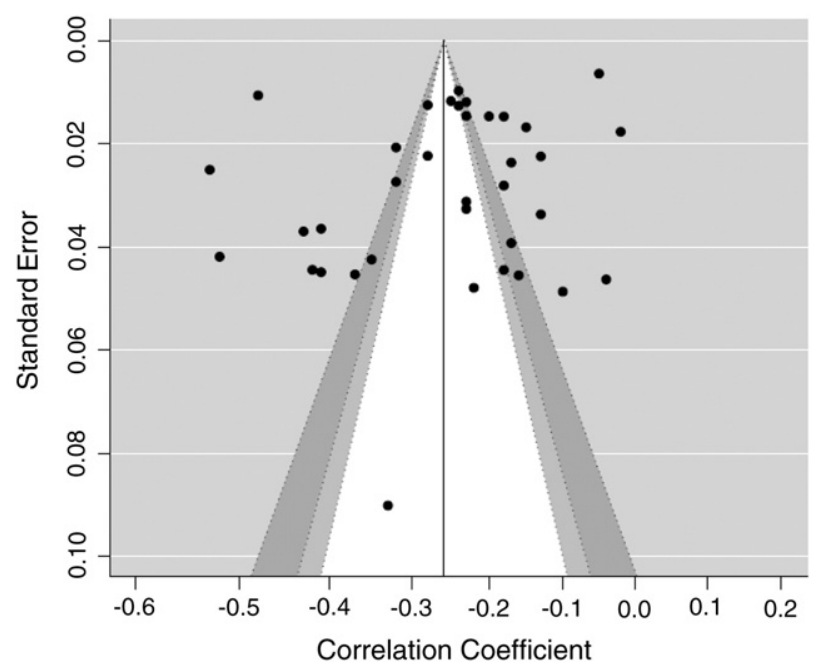

Fig. 4. Funnel plot of the transformed correlations. the sample size for the multiple meta-regression model. Therefore, this variable was not entered into the model. A total of 27 studies had complete data on the remaining moderators entered into the model.

After backward elimination, the final model contained the moderators school grade and publication year. The results for this model are shown in Table 5. The omnibus test of the two moderators was significant $(F(2,24)=4.37, p<.05)$. However, note that school grade is only significant at $\alpha=.10$. For this final model, $R^{2}=.18$. Considerable residual heterogeneity remained even with the inclusion of these two moderators $\left(Q=1224.26, d f=24, p<.0001,\left(\tau^{\wedge}=.14\right)\right.$.

Based on the model, the estimated average correlation in 1992 (the earliest publication year) was -.45 (95\% CI: -.56 to -.32 ) for the first school grade (the lowest school grade in the dataset). For 2011 (the latest publication year), the estimated average correlation was -.26 (95\% CI: -.37 to -.14 ), holding school grade constant at 1 . When setting school grade equal to 6 (the highest school grade in the dataset), then the estimated average correlation in 1992 and 2011 were -.26 ( $95 \% \mathrm{CI}:-.45$ to -.05$)$ and -.05 (95\% CI: -.22 to $.12)$, respectively. 


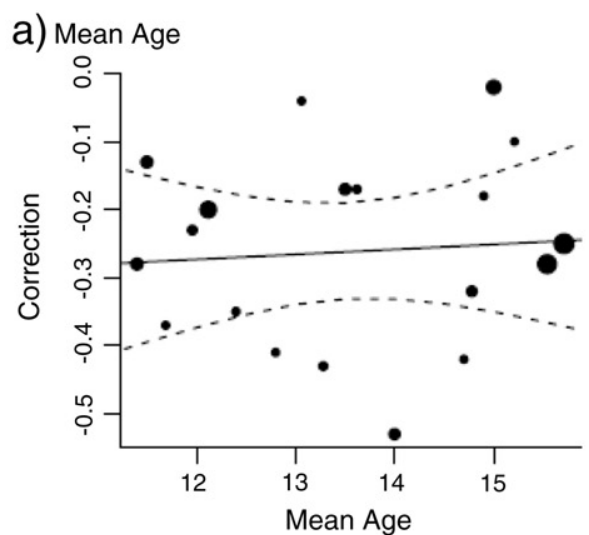

C) School Grade

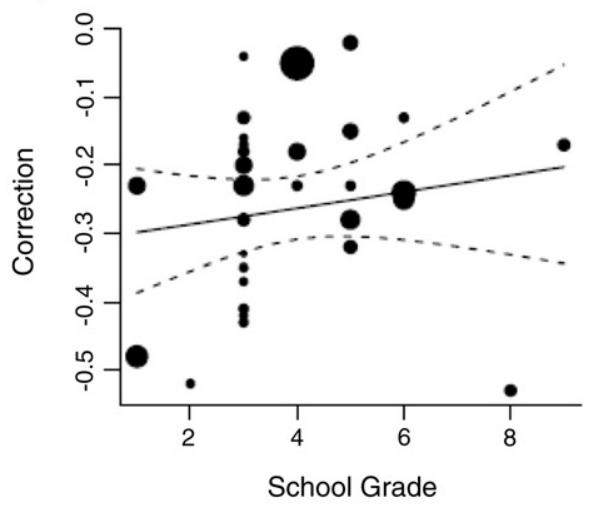

e)

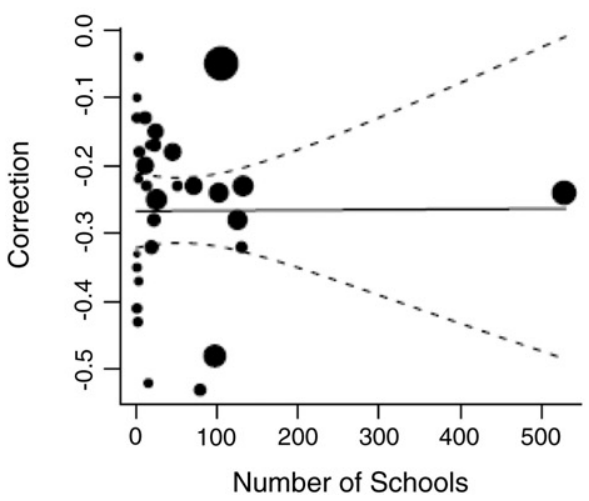

b) Percent Males

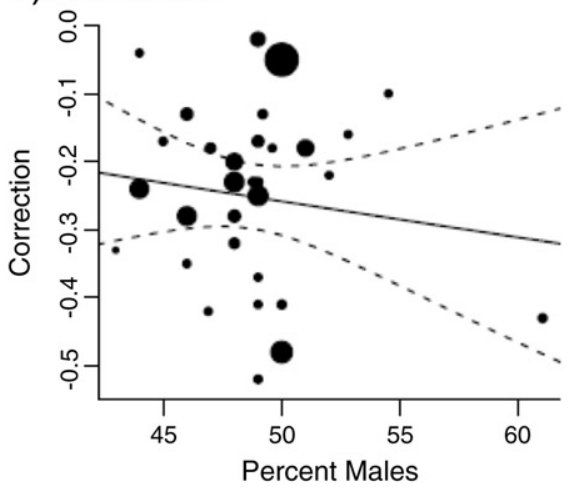

d) Survey Year

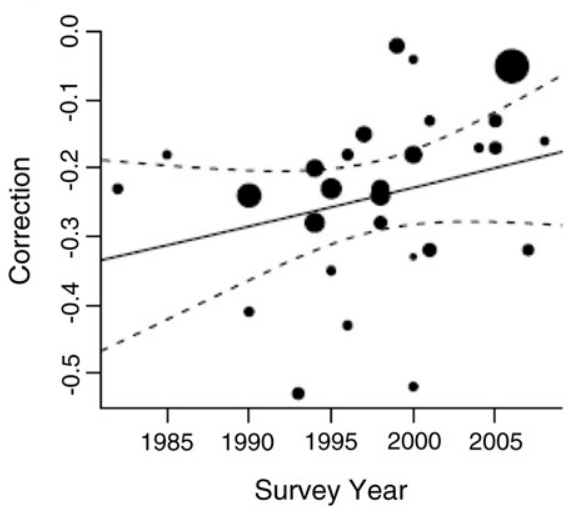

f) Publication Year

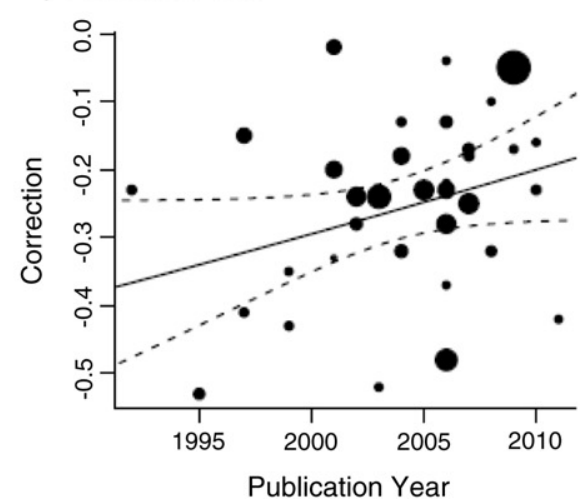

Fig. 5. Scatterplots for the continuous moderators.

Finally, as an alternative analysis strategy, the correlations were analyzed using a random-effects model based on the Hunter-Schmidt approach (Hunter \& Schmidt, 2004). The main differences compared to the initial approach are: (1) raw (instead of transformed) correlations are analyzed; (2) the individual correlations are corrected for

Table 3

Results for the univariate meta-regression models (continuous moderators).

\begin{tabular}{lcclrrc}
\hline Moderator & $\mathrm{k}$ & $\begin{array}{l}\text { Slope } \\
\text { coefficient }\end{array}$ & $\begin{array}{l}\text { Standard } \\
\text { error }\end{array}$ & t-value & $\mathrm{p}$-value & $\mathrm{R}^{2}$ \\
\hline Mean age & 19 & .0079 & .0255 & .31 & .76 & 0 \\
Percent males & 32 & -.0058 & .0077 & -.75 & .46 & 0 \\
School grade & 35 & .0128 & .0142 & .90 & .37 & 0 \\
Survey year & 28 & .0061 & .0043 & 1.41 & .17 & .28 \\
Number of schools & 32 & .0000 & .0003 & .03 & .98 & 0 \\
Publication year & 36 & .0101 & .0052 & 1.93 & .06 & .03 \\
\hline
\end{tabular}

attenuation (measurement error) in the two variables (i.e., the measure of school climate and the measure of school violence); (3) the HunterSchmidt estimator for the amount of heterogeneity is used.

For 10 out of the 36 studies (28\%), the reliability of the violence measurements was unavailable. Also, for 3 studies (8\%), the reliability of the climate measurements was unavailable. The mean reliability based on the available data (.77 for both the violence and the climate measurements) was substituted for the missing information. Fig. 7 shows a scatterplot of the observed versus the disattenuated correlations in the 36 studies. The effect of the attenuation correction is to increase the size of the correlations.

The estimated average correlation based on the random-effects model using the disattenuated correlations was -.32 (95\% CI: -.37 to -.27$)$. The amount of heterogeneity remained very large $(Q=2013.56, d f=35$, $\left.p<.0001 ; \mathrm{I} 2=98.1 \% ; \tau^{\wedge}=.17\right)$, which is also reflected in the wide $95 \%$ credibility interval ( -.58 to .00$)$. Although the estimated average 
Author, Year

Cernkovich, 1992
+ klicpera, 1995

+ Jenkins, 1997

+ Kuperminc, 1997

+ Thillmann, 1997

+ Bosworth, 1999

+ Mohr, 1999

+ Dunn, 2001

+ Sturzbecher, 2001

+ Welsh, 2001

+ Benbenishty, 2002

+ Roland, 2002

+ Cushing, 2003

+ Stewart, 2003

+ Galand, 2004

+ Kasen, 2004

+ Steffgen, 2004

+ Wilson, 2004

+ Heinrich, 2005

+ Astor, 2006

+ Brookmeyer, 2006

+ Graham, 2006

+ Loukas, 2006

+ Miller, 2006

+ Schechtman, 2006

+ Swearer,2006

+ Crooks, 2007

+ Nansel, 2007

+ Willoughby, 2007

+ Goldstein, 2008

+ Karwowski, 2008

+ Frey, 2009

+ O'Brennan, 2009

+ Lee, 2010

+ Pfetsch, 2010

+ Bayraktar, 2011
Correlation [95\%Cl]

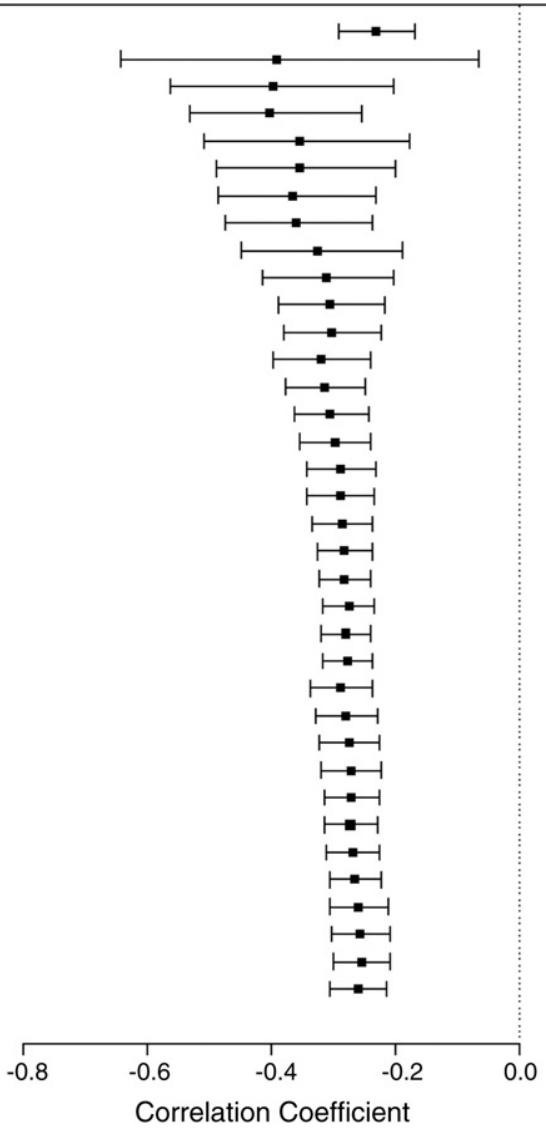

$-0.23[-0.29,-0.17]$

$-0.39[-0.64,-0.06]$

$-0.40[-0.56,-0.20]$

$-0.40[-0.53,-0.25]$

$-0.35[-0.51,-0.18]$

$-0.35[-0.49,-0.20]$

$-0.36[-0.48,-0.23]$

$-0.36[-0.47,-0.24]$

$-0.32[-0.45,-0.19]$

$-0.31[-0.41,-0.20]$

$-0.30[-0.39,-0.21]$

$-0.30[-0.38,-0.22]$

$-0.32[-0.40,-0.24]$

$-0.31[-0.38,-0.25]$

$-0.30[-0.36,-0.24]$

$-0.30[-0.35,-0.24]$

$-0.29[-0.34,-0.23]$

$-0.29[-0.34,-0.23]$

$-0.29[-0.33,-0.24]$

$-0.28[-0.33,-0.24]$

$-0.28[-0.32,-0.24]$

$-0.27[-0.32,-0.23]$

$-0.28[-0.32,-0.24]$

$-0.28[-0.32,-0.24]$

$-0.29[-0.34,-0.24]$

$-0.28[-0.33,-0.23]$

$-0.27[-0.32,-0.23]$

$-0.27[-0.32,-0.22]$

$-0.27[-0.31,-0.23]$

$-0.27[-0.31,-0.23]$

$-0.27[-0.31,-0.22]$

$-0.26[-0.31,-0.22]$

$-0.26[-0.31,-0.21]$

$-0.26[-0.30,-0.21]$

$-0.25[-0.30,-0.21]$

$-0.26[-0.30,-0.21]$

Fig. 6. Cumulative forest plot as a function of publication year.

correlation was slightly larger due to the disattentuation, the results are qualitatively very similar to those obtained earlier.

In conclusion, there appears to be a small- to medium-sized negative correlation between school climate and school violence. The average correlation falls (approximately) somewhere between - .20 and -.30 , depending on the model and analysis strategy. Outliers

Table 4

Results for the univariate meta-regression models (categorical moderators).

\begin{tabular}{|c|c|c|c|}
\hline Moderator/level & K & Estimated correlation & $95 \% \mathrm{CI}$ \\
\hline $\begin{array}{l}\text { Peer reviewed } \\
\text { - No } \\
\text { - Yes }\end{array}$ & $\begin{array}{r}7 \\
29\end{array}$ & $\begin{array}{l}-.17 \\
-.28 \\
F(1,34)=3.36, p=.08\end{array}$ & $\begin{array}{l}-.28 \text { to }-.07 \\
-.33 \text { to }-.23 \\
=.02\end{array}$ \\
\hline $\begin{array}{l}\text { Violence dimension } \\
\text { - Violence committed } \\
\text { - Violence experienced } \\
\text { - General perception }\end{array}$ & $\begin{array}{r}23 \\
10 \\
3\end{array}$ & $\begin{array}{l}-.23 \\
-.28 \\
-.36 \\
F(2,33)=1.47, p=.25\end{array}$ & $\begin{array}{l}-.29 \text { to }-.18 \\
-.37 \text { to }-.20 \\
-.50 \text { to }-.21 \\
=.09\end{array}$ \\
\hline $\begin{array}{l}\text { Climate dimension } \\
\text { - Relational } \\
\text { - Cognitive-affective } \\
\text { - Organizational }\end{array}$ & $\begin{array}{r}10 \\
17 \\
9\end{array}$ & $\begin{array}{l}-.27 \\
-.25 \\
-.26 \\
F(2,33)=0.03, p=.97\end{array}$ & $\begin{array}{l}-.35 \text { to }-.18 \\
-.32 \text { to }-.18 \\
-.35 \text { to }-.16 \\
=.01\end{array}$ \\
\hline $\begin{array}{l}\text { Continent } \\
\text { - North America } \\
\text { - Europe } \\
\text { - Asia }\end{array}$ & $\begin{array}{r}23 \\
9 \\
4\end{array}$ & $\begin{array}{l}-.25 \\
-.24 \\
-.35 \\
F(2,33)=1.07, p=.35\end{array}$ & $\begin{array}{l}-.31 \text { to }-.19 \\
-.32 \text { to }-.14 \\
-.47 \text { to }-.21 \\
=.14\end{array}$ \\
\hline
\end{tabular}

or overly influential studies do not appear to be present. There is also no indication of funnel plot asymmetry (which suggests the absence of publication bias). The school grade of the sample and the publication year of the study may be potential moderators, with stronger (more negative) correlations being found in earlier school grades and in studies published earlier.

\section{Discussion}

This meta-analysis showed a moderate negative relationship between students' perception of school climate and violence. Attempts to identify factors explaining this relation were not successful. Students' characteristics (age, gender), as well as school' characteristics (school size, school grade) could not be identified as clear moderators. Moreover, subdividing studies' measures into categories did not provide more information of greater effect size between relational, cognitive, affective or organizational school climate, neither did differentiations between committed, experienced or general perception of violence. These results lead to the conclusion that even if there is large heterogeneity in the theoretical and methodological aspects of school climate and school violence, the overall effect of the 36 studies

Table 5

Results for the multiple meta-regression model after backward elimination.

\begin{tabular}{lccrc}
\hline Moderator & Coefficient & Standard error & t-value & p-value \\
\hline Intercept & -23.243 & 11.019 & -2.11 & .05 \\
School grade & 0.027 & 0.014 & 1.94 & .07 \\
Publication year & 0.011 & 0.006 & 2.08 & .05 \\
\hline
\end{tabular}




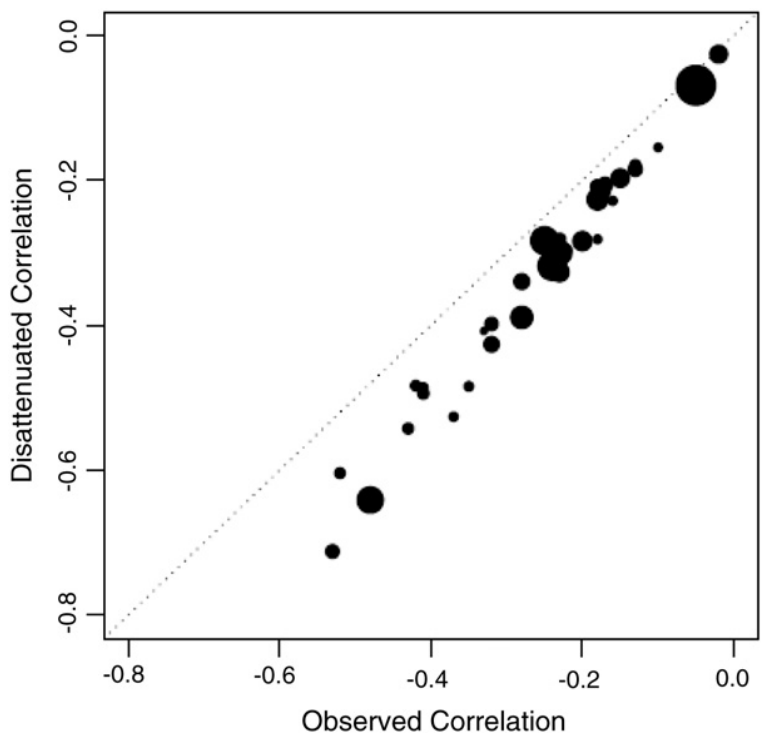

Fig. 7. Observed versus disattenuated correlations.

included in the meta-analysis underlined the impact of environmental factors on violent behaviors in schools. With this in mind, an expansive research agenda to better understand the relationship is needed. In particular, more and potentially better definitions and theories about both constructs and their relationship are called for.

\subsection{Limitations}

Some limitations have to be taken into account. First, the strength of the relationship between school climate and violence is difficult to assess due to the multiple measures of school climate and violence used by the included studies. This can partially be attributed to: (1) the multidisciplinary nature of the studies, and (2) to the fact that this research domain is new (Johnson, 2009). Second, a large number of studies using hierarchical modeling (HLM) have been excluded because the present meta-analysis is based on the individual perception of school climate. HLM procedures provide aggregated analyses on different levels which enable researchers to take into account the shared climate perception of a school.

\subsection{Perspectives}

The goal of this meta-analysis was to provide evidence for the relationship between school climate and school violence. This review suggests that by modifying the environmental factor of the school, violence behaviors can be reduced. Thus, it is recommended that future prevention program should target both individual and environmental factors of school violence. Beyond the classical notion that violence perpetrators are the main factors responsible for school violence, the role of the school as an entity should be questioned. Schools' educational and social functions influence the people's development, and should, therefore, be a priority in violence prevention programs.

\section{References}

Astor, R. A., Benbenishty, R., Vinokur, A. D., \& Zeira, A. (2006). Arab and Jewish elementary school students' perceptions of fear and school violence: Understanding the influence of school context. The British Journal of Educational Psychology, 76(1), 91.

Bayraktar, F. (2011). Bullying among adolescents in North Cyprus and Turkey: Testing a multifactor model. Journal of Interpersonal Violence, 20(10), 1-26.

Begg, C. B., \& Mazumdar, M. (1994). Operating characteristics of a rank correlation test for publication bias. Biometrics, 50(4), 1088-1101.
Benbenishty, R., Astor, R., Zeira, A., \& Vinokur, A. (2002). Perceptions of violence and fear of school attendance among junior high school students in Israel. Social Work Research, 26(2), 71-87.

Biostat (2008). Comprehensive Meta-Analysis Software version 2.2.048. Englewood, NJ: Bisotat.

Bosworth, K., Eseplage, D. L., \& Simon, T. R. (1999). Factors associated with bullying behavior in middle school students. The Journal of Early Adolescence, 19(3), 341-362

Bronfenbrenner, U. (1974). Developmental research, public policy, and the ecology of childhood. Child Development, 45, 1-5.

Brookmeyer, K. A., Fanti, K. A., \& Henrich, C. C. (2006). Schools, parents, and youth violence: A multilevel, ecological analysis. Journal of Clinical Child and Adolescent Psychology, 35(4), 504.

Carra, C. (2009). Pour une approche contextuelle de la violence: Le rôle du climat d'école. International Journal of Violence and School, 8, 2-23.

Cernkovich, S. A., \& Giordano, P. C. (1992). School bonding, race, and delinquency. Criminology, 30(2), 261-291.

Cochran, W. G. (1954). The combination of estimates from different experiments. Biometrics, 10, 101-129.

Crooks, C. V., Scott, K. L., Wolfe, D. A., Chiodo, D., \& Killip, S. (2007). Understanding the link between childhood maltreatment and violent delinquency: What do schools have to add? Child Maltreatment, 12(3), 269.

Cushing, L., Horner, R., \& Barrier, H. (2003). Validation and congruent validity of a direct observation tool to access student social climate. Journal of Positive Behavioral Interventions, 5(4), 225-237.

Debarbieux, E. (2006). Violence à l'école: un défi mondial? Paris: Armand Colin.

DerSimonian, R., \& Laird, N. (1986). Meta-analysis in clinical trials. Controlled Clinical Trials, 7(3), 177-188.

Dunn, A. -R. (2001). Relationships among school violence factors, school climate, school anxiety and learning outcomes in a middle school population. : University of Southern California.

Duval, S. J. (2005). The trim and fill method. In H. R. Rothstein, A. J. Sutton, \& M. Borenstein (Eds.), Publication bias in meta-analysis: Prevention, assessment, and adjustments (pp. 127-144). Chichester, England: Wiley.

Duval, S. J., \& Tweedie, R. L. (2000a). A nonparametric "trim and fill" method of accounting for publication bias in meta-analysis. Journal of the American Statistical Association, 95(449), 89-98.

Duval, S. J., \& Tweedie, R. L. (2000b). Trim and fill: A simple funnel-plot-based method of testing and adjusting for publication bias in meta-analysis. Biometrics, 56(2) 455-463.

Egger, M., Davey Smith, G., Schneider, M., \& Minder, C. (1997). Bias in meta-analysis detected by a simple, graphical test. British Medical Journal, 315(7109), 629-634.

Fisher, R. A. (1921). On the "probable error" of a coefficient of correlation deduced from a small sample. Metron, 1, 1-32.

Fraser, B. J. (1994). Research on classroom and school climate. In D. L. Gabel (Ed.), Handbook of research on science teaching (pp. 493-541). New York: Macmillan.

Freiberg, H. J. (1999). School climate: Measuring, improving, and sustaining healthy learning environments. London: Falmer Press.

Frey, A., Ruchkin, V., Martin, A., \& Schwab-Stone, M. (2009). Adolescents in transition: School and family characteristics in the development of violent behaviors entering high school. Child Psychiatry and Human Development, 40(1), 1-13.

Fuchs, M. (2009). Impact of school context on violence at schools. A multi-level analysis. International Journal on Violence and Schools, 7(1), 20-42.

Galand, B., Philippot, P., Petit, S., Born, M., \& Buidin, G. (2004). Regards croisés sur les phénomènes de violence en milieu scolaire: Elèves et équipes éducatives. Revue des Sciences de l'Education, 30(3), 465-486.

Goldstein, S. E., Young, A., \& Boyd, C. (2008). Relational aggression at school: Associations with school safety and social climate. Journal of Youth and Adolescence, 37(6), 641-654.

Gottfredson, D. C. (2001). Schools and delinquency. New York: Cambridge University Press.

Gottfredson, G. D., Gottfredson, D. C., Payne, A. A., \& Gottfredson, N. C. (2005). School Climate predictors of school disorder: Results from a national study of delinquency prevention in schools. Journal of Research in Crime and Delinquency, 42(4), 412-444.

Graham, S., Bellmore, A. D., \& Mize, J. (2006). Peer victimization, aggression, and their co-occurrence in middle school: Pathways to adjustment problems. Journal of Abnormal Child Psychology, 34(3), 363-378.

Hedges, L. V., \& Vevea, J. L. (1998). Fixed- and random-effects models in meta-analysis. Psychological Methods, 3, 486-504.

Henrich, C., Brookmeyer, K., \& Shahar, G. (2005). Weapon violence in adolescence: Parent and school connectedness as protective factors. Journal of Adolescent Health, 37(4), 306-312.

Hernandez, T. -J., \& Seem, S. -R. (2004). A safe school climate: A systemic approach and the school counselor. Professional School Counseling, 7(4), 256-262.

Higgins, J. P. T., Thompson, S. G., Deeks, J. J., \& Altman, D. G. (2003). Measuring inconsistency in meta-analyses. British Medical Journal, 327(7414), 557-560.

Hunter, J. E., \& Schmidt, F. L. (2004). Methods of meta-analysis: Correcting error and bias in research findings. London and Thousand Oaks, CA: Sage.

Janosz, M., Georges, P., \& Parent, S. (1998). L'environnement socioéducatif à l'école secondaire: Un modèle théorique pour guider l'évaluation du milieu. Revue Canadienne de Psycho-éducation, 27(2), 285-306.

Janosz, M., Thiébaud, M., Bouthillier, C., \& Brunet, L. (2005). Perception du climat scolaire et épuisement professionnel chez les enseignants. Paper presented at the Actes du XIIIème Congrès de Psychologie du Travail et des Organisations, Bologne, Italie.

Jenkins, P. H. (1997). School delinquency and the school social bond. Journal of Research in Crime and Delinquency, 34(3), 337-367.

Johnson, S. L. (2009). Improving the school environment to reduce school violence: A review of the literature. Journal of School Health, 79(10), 451-465. 
Karwowski, M. (2008). Creative climate as a preventive factor for youths' risk behaviours. New Educational Review, 16(3-4), 175-184.

Kasen, S., Berenson, K., Cohen, P., \& Johnson, J. -G. (2004). The effects of school climate on changes in aggressive and other behaviors related to bullying. In S. M. E. Swearer, \& D. L. Espelage (Eds.), Bullying in American schools: A social-ecological perspective on prevention and intervention (pp. 187-210). Mahwah, NJ, US: Lawrence Erlbaum Associates Publishers.

Klicpera, C., Gasteiger, K., \& Schabmann, A. (1995). Wieweit tragen schul-bzw. klassenspezifische Faktoren zur Aggression an den Schulen bei? Zeitschrift für Kinder- und Jugendpsychiatrie und Psychotherapie, 23, 243-254.

Knapp, G., \& Hartung, J. (2003). Improved tests for a random effects meta-regression with a single covariate. Statistics in Medicine, 22(17), 2693-2710.

Konstantopoulos, S., \& Hedges, L. V. (2009). Fixed effects models in meta-analysis. In H. Cooper, L. V. Hedges, \& J. Valentine (Eds.), The handbook of research synthesis and meta-analysis (pp. 279-294). (2nd Ed.). New York: Russell Sage.

Kuperminc, G. P., Leadbeater, B. J., Emmons, C., \& Blatt, S. J. (1997). Perceived school climate and difficulties in the social adjustment of middle school students. Applied Developmental Science, 1(2), 76-88.

Lee, C. H. (2010). An ecological systems approach to bullying behaviors among middle school students in the United States. Journal of Interpersonal Violence, 3, 1-30.

Light, R. J., \& Pillemer, D. B. (1984). Summing up: The science of reviewing research. Cambridge, Massachusetts: Harvard University Press.

Loukas, A., Suzuki, R., \& Horton, K. D. (2006). Examining school connectedness as a mediator of school climate effects. Journal of Research on Adolescence, 16(3), 491-502.

Miller, C. -K. (2006). Student and teacher perceptions of school social climate and attitudes toward bullying: Implications for intervention. : The University of Nebraska.

Mohr, A. (1999). Das Erleben von Gewalt und Aggressionen in der Schule-Ein Ansatzpunkt für die schulische Gesundheitsförderung? Zeitschrift für Gesundheitspsychologie, 7(4), 203-212.

Moos, R. H. (1979). Evaluating educational environments: Procedures, measures, findings, and policy implications. San Francisco: Jossey-Bass.

Nansel, T. -R., Haynie, D. -L., \& Simons-Morton, B. -G. (2007). The association of bullying and victimization with middle school adjustment. In C. A. E. Maher, J. E. E. Zins, \& M. J. E. Elias (Eds.), Bullying, victimization, and peer harassment: A handbook of prevention and intervention (pp. 49-65). New York, NY, US: Haworth Press.

O'Brennan, L. M., Bradshaw, C. P., \& Sawyer, A. L. (2009). Examining developmenta differences in the social-emotional problems among frequent bullies, victims, and bully/victims. Psychology in the Schools, 46(2), 100-115.

Olweus, D. (2004). The Olweus Bullying Prevention Programme: Design and implementation issues and a new national initiative in Norway. In P. K. Smith, D. Pepler, \& K. Rigby (Eds.), Bullying in schools: How successful can interventions be? (pp. 13-36). : Cambridge University Press.

Peters, J. L. Sutton, A. J. Jones, D. R, Abrams, K. R, \& Rushton, L. (2008). Contour-enhanced meta-analysis funnel plots help distinguish publication bias from other causes of asymmetry. Journal of Clinical Epidemiology, 61(10), 991-996.

Pfetsch, J. (2010). Zivilcourage in der Schule. Konzeption und Evaluation eines Zivilcourage-Trainings zur Prävention aggressiven Verhaltens unter Schülern. Luxembourg: University of Luxembourg.

Raudenbush, S. W. (2009). Analyzing effect sizes: random-effects models. In H. Cooper, L. V. Hedges, \& J.C., V. (Eds.), The handbook of research synthesis (pp. 295-315) New York: Russell Sage Foundation.
Riley, R. D., Higgins, J. P., \& Deeks, J. J. (2011). Interpretation of random effects metaanalyses. British Medical Journal, 342, d549.

Roland, E., \& Galloway, D. (2002). Classroom influences on bullying. Educational Research, 44(3), 299-312.

Schechtman, Z. (2006). The relationship of life skills and classroom climate to self-reported levels of victimization. International Journal for the Advancement of Counselling, 28(4), 359-373.

Smith, P. K. (2000). Bullying and harassment in schools and the rights of children. Children E Society, 14, 294-303.

Smith, P. K. (2005). Tackling violence in schools: A European perspective. In C. e Gittins (Ed.), Europe and violence in schools - How to make a difference, a handbook (pp. 11-22). : Council of Europe.

Smith, P. K., Ananiadou, K., \& Cowie, H. (2003). Interventions to reduce school bullying. Canadian Journal of Psychiatry, 48(9), 591-599.

Steffgen, G. (Ed.). (2004). Schulkultur und Gewalt in der Schule - Untersuchungen zu Schulraumqualität, Klassenklima und Lehrerprofessionalität, Gewalt an Luxemburger Schulen. Stand der Forschung. Luxembourg: Imprimerie Saint-Paul.

Steffgen, G. (2009). Deviant behaviour and violence in Luxembourg schools. International Journal on Violence and Schools, 5, 54-70.

Sterne, J. A. C., \& Egger, M. (2005). Regression methods to detect publication and other bias in meta-analysis. In H. R. Rothstein, A. J. Sutton, \& M. Borenstein (Eds.), Publication bias in meta-analysis: Prevention, assessment and adjustments (pp. 99-100). Chichester, UK: Wiley.

Stewart, E. A. (2003). School social bonds, school climate, and school misbehavior: A multilevel analysis. Justice Quarterly, 20(3), 575-601.

Sturzbecher, D., Landua, D., \& Shahla, H. (2001). Jugendgewalt unter ostdeutschen jugendlichen; violence among eastern german adolescents Jugend in ostdeutschland: Lebenssituationen und delinquenz Leske + Budrich: Opladen (pp. 249-300).

Swearer, M., Peugh, J, Espelage, D, Siebecker, A. Kingsbury, W \& Bevins, K. (2006). A social ecological model for bullying prevention and intervention in early adolescence: An explanatory. In M. Furlong, \& S. Jimerson (Eds.), Handbook of school violence and school safety: From research to practice examination: Routledge (pp. 257-275).

Tillmann, K. -J., Holler-Nowitzki, B., Holtappels, H. G., Meier, U., \& Popp, U. (Eds.). (1997). Schülergewalt als Schulproblem. Verursachende Bedingungen, Erscheinungsformen und pädagogische Handlungsperspektiven. Weinheim/München: Juventa.

Viechtbauer, W. (2010). Conducting meta-analyses in R with the metafor package. Journal of Statistical Software, 36, 1-48.

Viechtbauer, W., \& Cheung, M. W. -L. (2010). Outlier and influence diagnostics for meta-analysis. Research Synthesis Methods, 1(2), 112-125.

Welsh, W. N. (2001). Effects of student and school factors on five measures of school disorder. Justice Quarterly, 18(4), 911-947.

Willoughby, T., Chalmers, H., Busseri, M. A., Bosacki, S., Dupont, D., Marini, Z., et al. (2007). Adolescent non-involvement in multiple risk behaviors: An indicator of successful development? Applied Developmental Science, 11(2), 89-103.

Wilson, D. (2004). The interface of school climate and school connectedness and relationships with aggression and victimization. Journal of School Health, 74(7), 293-299. 